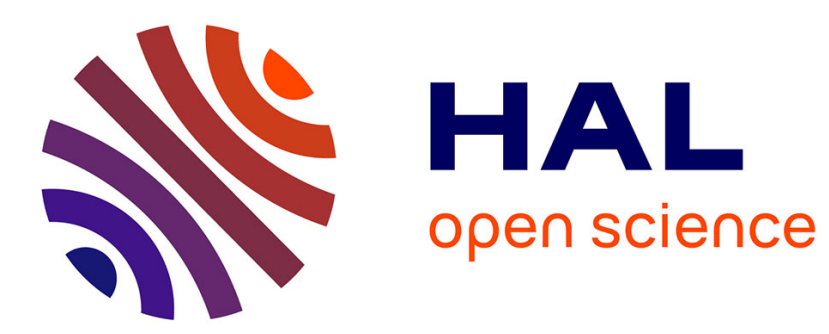

\title{
Diversity and habitat use by stingless bees (Apidae) in the Brazilian Atlantic Forest
}

Marília Silva, Mauro Ramalho, Daniela Monteiro

\section{To cite this version:}

Marília Silva, Mauro Ramalho, Daniela Monteiro. Diversity and habitat use by stingless bees (Apidae) in the Brazilian Atlantic Forest. Apidologie, 2013, 44 (6), pp.699-707. 10.1007/s13592-013-0218-5 . hal-01201339

\section{HAL Id: hal-01201339 \\ https://hal.science/hal-01201339}

Submitted on 17 Sep 2015

HAL is a multi-disciplinary open access archive for the deposit and dissemination of scientific research documents, whether they are published or not. The documents may come from teaching and research institutions in France or abroad, or from public or private research centers.
L'archive ouverte pluridisciplinaire HAL, est destinée au dépôt et à la diffusion de documents scientifiques de niveau recherche, publiés ou non, émanant des établissements d'enseignement et de recherche français ou étrangers, des laboratoires publics ou privés. 


\title{
Diversity and habitat use by stingless bees (Apidae) in the Brazilian Atlantic Forest
}

\author{
Marília Dantas E. Silva ${ }^{1,2}$, Mauro Ramalho ${ }^{1}$, Daniela Monteiro ${ }^{1}$ \\ ${ }^{1}$ Laboratório de Ecologia da Polinização, ECOPOL, Instituto de Biologia, Departamento de Botânica, Universidade \\ Federal da Bahia, Campus Universitário de Ondina, Rua Barão do Jeremoabo s/n, Ondina, CEP 40170-115, \\ Salvador, Bahia, Brazil \\ ${ }^{2}$ Instituto Federal de Educação, Ciência e Tecnologia Baiano, Campus Governador Mangabeira, Rua Waldemar \\ Mascarenhas, s/n—Portão, CEP 44350000, Governador Mangabeira, Bahia, Brazil
}

Received 28 August 2012 - Revised 16 May 2013 - Accepted 27 May 2013

\begin{abstract}
The present study discusses spatial variations in the community structure of stingless bees as well as associated ecological factors by comparing the nest densities in two stages of forest regeneration in a Brazilian Tropical Atlantic rainforest. The stingless bee nests were sampled in sixty-four $25 \times 25 \mathrm{~m}$ plots ( 4 ha) in four replicates of two forest categories: (a) mature, or old growth, stage of forest regeneration and (b) early-stage forest regeneration. Tree cavities were the major nesting substrate, and 91 nests were found within the total sampling area of 32 ha ( 2.8 nests/ha), constructed by 12 stingless bee species. The four most abundant species showed no significant differences in terms their use of tree circumference at breast height $(\mathrm{CBH})$ categories between 60 and $150 \mathrm{~cm}$. The spatial distributions of the $\mathrm{CBH}$ categories were mainly random or uniform, and the principal difference between the forest stages was the density of their largest trees $(\mathrm{CBH}>110 \mathrm{~cm})$. This structural difference in the vegetation contrasted with the small spatial variation $(p>0.05)$ of the stingless bee community structure (species composition, richness, and nest abundance). This unexpected spatial homogeneity could be related to similar and abundant availabilities of the largest nesting sites and to the existence of similar mechanisms controlling cavity use in both forest categories. The low nestper-tree frequency $(1$ nest per 100 trees with $\mathrm{CBH}>60 \mathrm{~cm}$ ), for instance, suggests that the availability of tree nesting sites is not limiting stingless bees. Alternatively, the stochasticity that permeates the temporal dynamics of highly diverse tree communities may also neutralize any latent competition between stingless bees.
\end{abstract}

\section{Meliponini / nesting / arboreal substrates}

\section{INTRODUCTION}

Bees of the tribe Meliponini live in large, perennial, sessile, eusocial colonies, and they are frequently the most numerous group of flowervisiting insects in tropical forests (Roubik 1989; Michener 2000). Given their high demands for floral resources and the high turnover of colony biomass (Roubik 1993; Kleinert et al. 2012), these bees are expected to be found in limited member-

Corresponding author: M.D.E. Silva, ailirambio@hotmail.com

Manuscript editor: James Nieh ship communities (sensu Roughgarden 1989). This premise is supported by their diverse behavioral strategies of food use and their monopolization of rich sources (Johnson and Hubbell 1974, 1975; 1987), high interspecific trophic niche overlap (Kleinert et al. 2012), and the apparent limiting similarity in species composition (e.g., Biesmeijer and Slaa 2006).

In general, stingless bees use a variety of nesting substrates. However, they are dependent on preexisting cavities in trees and rocks, and holes in the ground, including nests abandoned by other social insects - except for a very small number of 
species that make exposed nests (Nogueira-Neto 1970, 1997; Vergara et al. 1986; Roubik 1989; Michener 2000). Hubbell and Johnson (1977) suggested that the structures of stingless bee communities in tropical forests could be limited by nesting site competition. Although this argument appears in subsequent studies by various authors (e.g., Roubik 2006), no field studies have yet provided reliable data for the systematic analysis of the role of nest substrate availability on their populations.

Eltz et al. (2002) argued that the availability of potential nesting substrates would not be as important as the unpredictable mass-flowering pattern in limiting nest density in undisturbed SE Asian dipterocarp forests. Most stingless bees are flower generalists (Biesmeijer and Slaa 2006), although Ramalho (2004) noted a tight association between stingless bees and mass-flowering trees in the canopies of Brazilian Atlantic rainforest. Different behavioral strategies influence which food sources are chosen and how they are exploited by different species within a community (e.g., Johnson and Hubbell 1974, 1984; Johnson et al. 1987) and flower resource utilization patterns are profoundly affected by species types (e.g., Ramalho 1990; Ramalho et al. 2007; Kleinert et al. 2012). In summary, both floral resources and nesting sites could limit nest density, species composition, and diversity among stingless bee communities.

There is empirical evidence that spatial heterogeneity at the local landscape level influences nest density and species composition in stingless bee communities (e.g., Eltz et al. 2002, 2003; Slaa 2006). The existence of different habitat types in a given landscape tends to promote spatial diversity (Adams 2009) because they favor species using different strategies. Slaa (2006) concluded that life histories (and principally colony survival) among stingless bees were affected by both species and habitat types in tropical lowlands of Central America.

Stingless bees reproduce in sessile social colonies, so nest surveys should provide reasonably accurate measures of effective population sizes (e.g., Brown and Albrecht 2001; Kleinert 2006) and the relative abundances of species within the focal communities. Few studies of stingless bee commu- nity structures in tropical forests have been based on colony surveys, and most of these investigations did not analyze habitat-related ecological variables. Studies of this type have been undertaken in tropical dry and rain forests in Central America (Hubbell and Johnson 1977; Roubik 1983), lowland forests and savannas in French Guiana (Roubik 1979), the Amazon rainforest (Oliveira et al. 1995), the Brazilian Atlantic rainforest (Batista et al. 2003), and the tropical lowland dipterocarp forests of Malaysia (Eltz et al. 2002).

The present study compares the community structures of stingless bee colonies in mature and early-stage forest regeneration sites in the Brazilian Atlantic rainforest of eastern Brazil. Our objective was to test for spatial variations in the patterns of species composition, richness, and abundance as a function of their species-specific attributes and the structural characteristics of the forest categories (mainly the distributions of tree nesting sites).

\section{MATERIALS AND METHODS}

The present study was conducted in the Michelin Ecological Reserve-MER $\left(13^{\circ} 50^{\prime} \mathrm{S}, 39^{\circ} 15^{\prime} \mathrm{W}\right)$ in the Brazilian Atlantic rainforest in northeastern Brazil. The MER encompasses 3,096 ha of tropical rainforest at altitudes from 160 to 327 masl. The native forest forms a mosaic with rubber (Hevea brasiliensis Muell. Arg., Euphorbiaceae) plantations. Regional temperatures range from 18 to $30^{\circ} \mathrm{C}$, with high relative humidity $(80-85 \%)$ and an average annual precipitation of approximately $2,015 \mathrm{~mm}$ that is evenly distributed throughout the year (type Af, according to Köppen 1948) (CEI-CONDER 1993).

The MER forest areas experienced severe anthropogenic impacts prior to 2004, generating a mosaic of forest fragments at different stages of regeneration. At the present time, the preserved nuclear areas of the largest fragments have attained a mature old growth stage of regeneration, with canopy heights of more than $20 \mathrm{~m}$ and many trees with circumferences $>190 \mathrm{~cm}$ at breast height, as well as numerous old growth trees $>300 \mathrm{~cm}$ in circumference. There are also extensive patches of forest at early stages of regeneration (with lower canopies and no old growth trees and with greater shrub and herbaceous plant cover), mainly at the edges of the largest intact fragments (Flesher 2006). 
Four replicates of the two forest categories were sampled in each of the four largest MER forest fragments (Pacange, Luis Inacio, Vila 5, and Pancada Grande): mature (or old growth) and early-stage regeneration (Figure 1). Nest surveys were made during 5 days of fieldwork per month, between July 2007 and January 2010. Visual searches were conducted (with and without binoculars), with special attention being paid to large trees with circumferences at breast height $(\mathrm{CBH})>190 \mathrm{~cm}$ - in which stingless bee nests tend to be concentrated in forest habitats (Eltz et al. 2002; Batista et al. 2003). Other potential nesting sites, such as rock outcrops and termite nests, were likewise inspected in each plot. The sampling effort during each replicate was proportional to the time necessary to search all of the trees and potential nesting sites in each plot (see below).
Points were established along preexisting trails within each habitat type in the MER fragments for implanting $25 \times 25 \mathrm{~m}$ plots. A total of 64 plots were established and sampled in each of the four replicates (total area of 4 ha), for an overall total of 16 ha for each of the two forest categories. The 64 plots were located at least $50 \mathrm{~m}$ from each another in order to avoid overlapping sampling areas.

The nests were identified and geo-referenced (GPS Garmin Map 60CS), and the following characteristics were recorded: substrate type, tree $\mathrm{CBH}$, and height of the nest entrance. Samples of approximately ten worker bees were collected from each observed nest for species identifications. The bee specimens were mounted, labeled, and morphotyped in the Pollination Ecology Laboratory (ECOPOL) of the Biology Institute of the Federal University of Bahia (UFBA) in Salvador, Bahia State, Brazil. The specimens were identified by Dr.

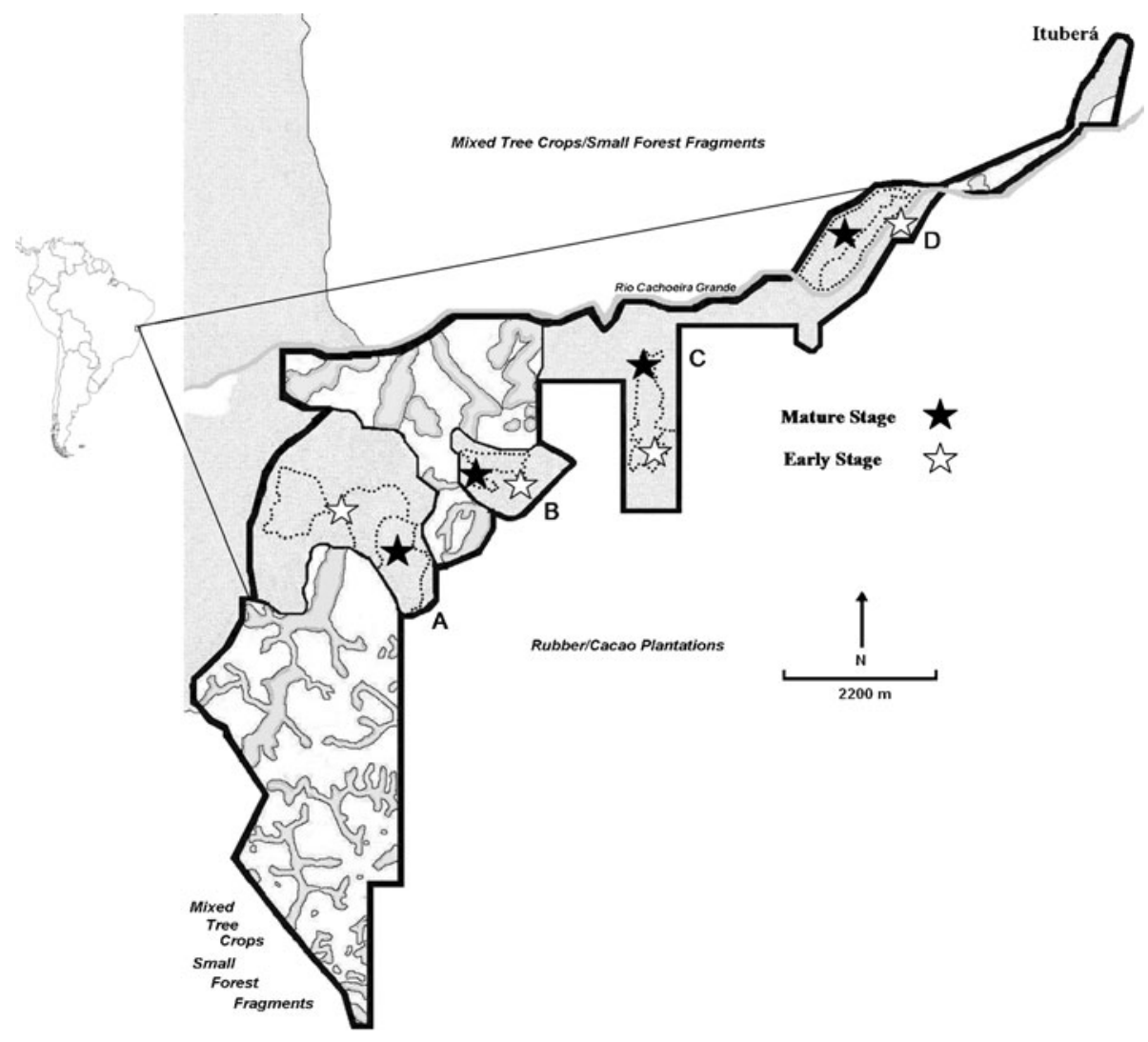

Figure 1 Location of the large forest fragments surveyed in the Brazilian Atlantic rainforest at the MER: $A$ Pacange, $B$ Luis Inacio, $C$ Vila 5 , and $D$ Pancada Grande 
Favizia Freitas de Oliveira of the Insect Bionomics, Biogeography, and Systematics Laboratory (BIOSIS) at the same institution. Specimens were deposited in the Zoology Museum at the Federal University of Bahia (MZUFBA).

The structures of the arboreal vegetation in each forest regeneration type were quantified using the Tsquare method (Sutherland 1996), in which 20 points were selected randomly within each plot, and the distances to the nearest tree were measured, followed by the distance to the nearest neighbor on the orthogonal plane from the first tree. These two measures were used to estimate the density and spatial distributions of living trees in four $\mathrm{CBH}$ categories: $1=21-$ $50 \mathrm{~cm}, 2=51-80 \mathrm{~cm}, 3=81-110 \mathrm{~cm}$, and $4>110 \mathrm{~cm}$.

The densities and spatial distributions of the trees (the structure of the arboreal vegetation) were evaluated using the nearest neighbor dispersal index, R (Clark and Evans 1954), using the Ecological Methodology software program, second edition (Kenney and Krebs 2000). The spatial distribution index represents the ratio between the mean observed distance between nearest neighbors and the mean distance expected if the distribution was random (clumped distribution, $R<0$; random distribution, $R=1$; uniform distribution, $R>1$ ).

Nonparametric multivariate analysis of variance NP-MANOVA (Anderson 2005; McCune and Grace 2002) was used to evaluate changes in the abundances, richnesses, and species compositions of stingless bees in the two different stages of forest regeneration (considered here as "landscape elements"). This procedure was selected due to the non-normal distribution of the data and their heterogeneous variances. The normality of the data was evaluated using the Kolmogorov-Smirnov test, run on GraphPad Instat 3.05 software (GraphPad Software 1998). Homoscedasticity was assessed using Levene's test for homogeneity of variance, run on SPSS software (SPSS ${ }^{\circledR} 13.0$ for Windows ${ }^{\circledR}$, SPSS Inc., Chicago, IL, USA). The protocol analysis included a sample size equal to four (replicates) with a single factor: the landscape elements, with its two categories being the stages of forest regeneration (early stage (ES) and mature stage (MS)). No data standardization was performed, and the Bray-Curtis distance measure was used (Bray and Curtis 1957), with $\alpha=0.05$ (Anderson 2005).

The reliability of the samples was assessed through a cumulative species curve, produced using the R platform, version 2.13 (R Development Core Team 2011). The Chaol species richness estimator (Chao 2005) was used to estimate the minimum number of undetected species based on the frequencies of the rare species in the sample: Sest= Sobs $+(\mathrm{f} 1) 2 / 2(\mathrm{f} 2)$, where Sest $=$ theoretical number of species and Sobs $=$ the number of species recorded, with (f1)2/2(f2) representing the ratio of the numbers of species in the sample with one or two specimens.

\section{RESULTS}

A total of 91 stingless bee nests were found in the 32 ha of forest sampled at the MER, giving an average of 2.8 nests per hectare. Approximately 300 trees with $\mathrm{CBH}>50 \mathrm{~cm}$ were recorded per hectare (Table I), which is equivalent to one bee nest per hundred trees. The density of the largest trees $(\mathrm{CBH}>110 \mathrm{~cm})$ was two to three times higher in the mature forest as compared to the early successional forest (Table I); smaller trees $(\mathrm{CBH}>20 \mathrm{~cm}<80 \mathrm{~cm})$ were distributed more uniformly. Considering the whole range of $\mathrm{CBH}$ classes, the spatial distributions of trees were predominantly uniform (72\%), rather than random $(28 \%)$, in both types of habitat. Therefore, the main component of spatial heterogeneity in the vegetation structure is due to old growth trees, which might be expected to cause spatial variations in parameters such as the abundances of the species that form large colonies.

A total of 12 species of stingless bees were identified, distributed among eight genera, although only four species had relative abundances higher than $10 \%$ (Tetragonisca angustula, Scaptotrigona xanthotricha, Scaptotrigona bipunctata, and Melipona scutellaris) (Figure 2a). The other species were represented by just one to three nests. The Chao 1 species richness estimator indicated a theoretical absence of 6.25 rare species in the samples, and five additional stingless bee species were recorded within the study area using mixed complementary methods (Silva et al., unpublished data). Therefore, the nest survey may have missed species with inconspicuous nests, and we cannot make 
Table I. Densities (trees per hectare) and spatial distributions of living trees in four replicas of each forest category: early (ES) and mature (MS) stages of forest regeneration in the Brazilian Atlantic rainforest at MER

\begin{tabular}{clllllllll}
\hline & & ES1 & ES2 & ES3 & ES4 & MS1 & MS2 & MS3 & MS4 \\
\hline Tree CBH & 1 & $719.3 / \mathrm{U}$ & $565 / \mathrm{U}$ & $589.5 / \mathrm{U}$ & $525.2 / \mathrm{U}$ & $936.4 / \mathrm{R}$ & $409.5 / \mathrm{R}$ & $404.5 / \mathrm{U}$ & $396.2 / \mathrm{U}$ \\
categories & 2 & $216.8 / \mathrm{U}$ & $120.3 / \mathrm{U}$ & $110.8 / \mathrm{R}$ & $212.5 / \mathrm{U}$ & $320 / \mathrm{U}$ & $322.6 / \mathrm{U}$ & $205.9 / \mathrm{U}$ & $179.8 / \mathrm{U}$ \\
& 3 & $45.7 / \mathrm{U}$ & $55.9 / \mathrm{U}$ & $75.7 / \mathrm{U}$ & $67.6 / \mathrm{R}$ & $97 / \mathrm{R}$ & $96.2 / \mathrm{U}$ & $110.2 / \mathrm{U}$ & $68.5 / \mathrm{U}$ \\
& 4 & $34.6 / \mathrm{U}$ & $39.1 / \mathrm{U}$ & $55 / \mathrm{U}$ & $35.6 / \mathrm{U}$ & $118.7 / \mathrm{R}$ & $87.2 / \mathrm{U}$ & $71.7 / \mathrm{R}$ & $107.7 / \mathrm{R}$ \\
\hline
\end{tabular}

Tree CBH categories: $1=20-50 \mathrm{~cm}, 2=51-80 \mathrm{~cm}, 3=81-110 \mathrm{~cm}$, and $4>110 \mathrm{~cm}$. Nearest neighbor index of dispersal (Clark and Evans 1954): $R>1=$ uniform (U); $R=0=$ random (R)
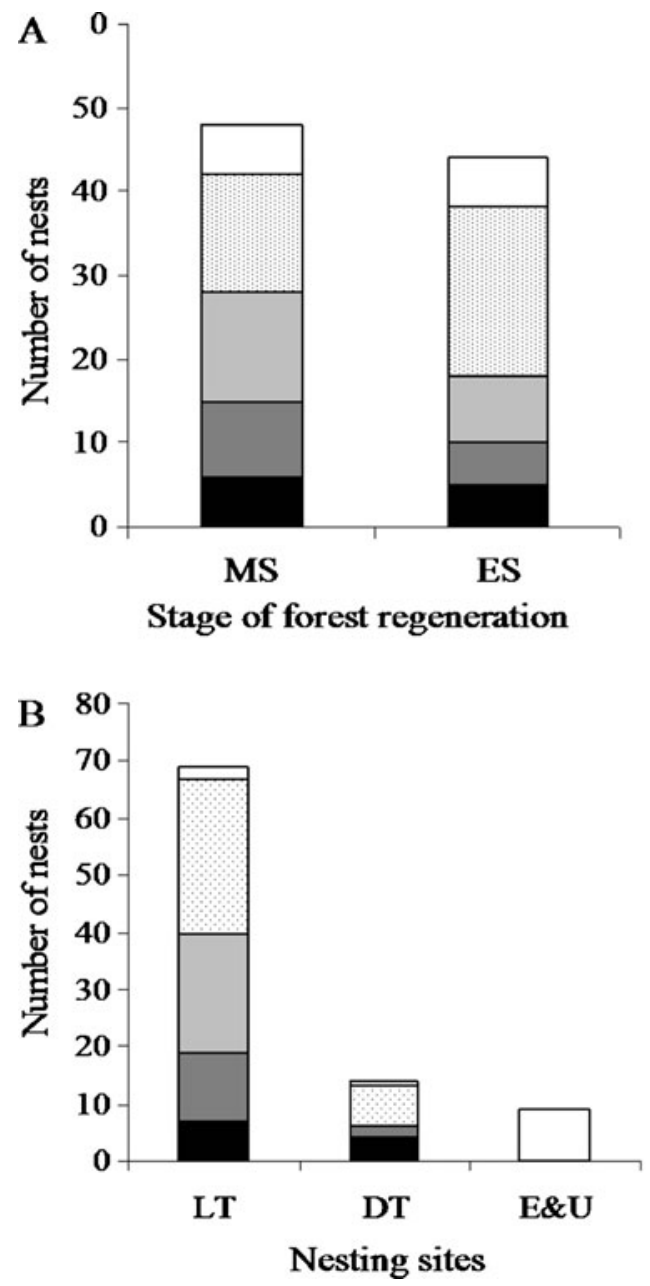

$\square$ Others Meliponins

Tetragonisca angustula (Latreille, 1811)

Scaptotrigona xanthotricha Moure, 1950

Scaptotrigona bipunctata (Lepeletier, 1836)

Melipona scutellaris Latreille, 1811

Figure 2 Abundance of stingless bee nests in each stage of forest regeneration (MS, ES) and in different nesting sites (LT, DT, E, and $\mathrm{U}$ ) in the Brazilian Atlantic rainforest (MER). $M S=$ mature stage of forest regeneration, $E S$ = early stage, $L T=$ live tree, $D T=$ dead tree, $E=$ exposed, $U=$ underground. Other meliponins: Partamona sp. 1; Partamona sp. 2; Scaura atlantica Melo, 2004; Trigona braueri Friese, 1900 (=Trigona fulviventris Guérin, 1835), Paratrigona subnuda Moure, 1947; Plebeia droryana Friese, 1900; Trigona fuscipennis Friese 1900; Trigona spinipes (Fabricius, 1793) 
any statements on species that remained undetected due to their general rarity. In contrast, the cumulative species curves tended towards saturation (Figure 3), indicating that the sample size was satisfactory for comparative analyses of the two forest categories. Eight species were recorded in each of the two forest categories (MS and ES of forest regeneration), but only four species were common to both categories. The species Partamona sp1 and sp2, Scaura atlantica, and Trigona braueri were recorded exclusively in the mature forest, while Paratrigona subnuda, Plebeia droryana, Trigona spinipes, and Trigona fuscipennis were particularly observed in the early successional habitat (see other bees in Figure 2a). All of these exclusive species were rarely sampled, so that any apparent differences between the two forest categories should be considered with caution.

Overall, the stingless bee community showed a weak response to spatial variations in vegetation structure (e.g., the density of trees with $\mathrm{CBH}>$ $110 \mathrm{~cm}$ ) between the two forest categories (Table II). No significant differences were noted in species richness and composition between the two stages of forest regeneration. The four most abundant bee species were equally common in both forest categories, although these bees are quite

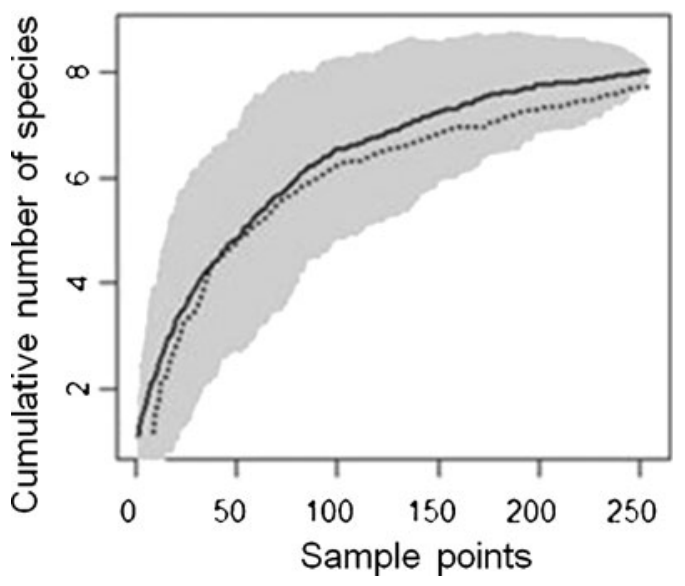

Figure 3 Cumulative species curve (sampling reliability) of stingless bees in mature (dotted line) and early (continuous line) stages of forest regeneration, in the Brazilian Atlantic rainforest in the MER, Bahia State, Brazil
Table II. Influence of forest categories (FC) on species composition, species richness, and the nest abundance of locally abundant species of stingless bees in the Brazilian Tropical Atlantic rainforest at MER

\begin{tabular}{ll}
\hline Dependent variable & FC $(p)$ \\
\hline Species composition & 0.5840 \\
Species richness & 0.1460 \\
Total Sbees & 0.6740 \\
Melipona scutellaris & 0.1770 \\
Scaptotrigona xanthotricha & 0.4090 \\
Scaptotrigona bipunctata & 0.8910 \\
Tetragonisca angustula & 0.6202
\end{tabular}

$F C$ early and mature stages of forest regeneration; $p$ probability, Total Sbees total abundance of stingless bee nests (12 species)

distinct from one another (Figure 2b): $M$. scutellaris, for example, is a relatively large species (10-12 mm) with high colony biomasses and low swarming rates, while Scaptotrigona species are small bees $(6-7 \mathrm{~mm})$ that live in very populous colonies and demonstrate group foraging strategies; T. angustula is the smallest species (5-6 mm), with populous colonies and very high swarming rates.

With the exception of $M$. scutellaris, the three other abundant species showed considerable overlap in their nesting heights (Figure 4a). The four most abundant species nested in trees with very similar diameters $(\mathrm{CBH}>60 \mathrm{~cm}<$ $150 \mathrm{~cm}$ ) and may thus be using tree hollows of similar sizes (Figure 4b). It is noteworthy that both Scaptotrigona species overlap considerably in terms of tree size and nesting heights.

\section{DISCUSSION/CONCLUSION}

The observed densities of stingless bee nests in continuous tropical rainforests tend to be relatively low, i.e., 0.15 to 6.0 nests/ha (Hubbell and Johnson 1977; Roubik 1983, 2006; Oliveira et al. 1995; Eltz et al. 2002; Slaa 2006), considering the high availability of tree hollows in these habitats (e.g., Eltz et al. 2003). The low nest densities and nest-per-tree frequencies (approximately 1 bee nest per 100 trees with $\mathrm{CBH}>50 \mathrm{~cm}$ ) seen in the 

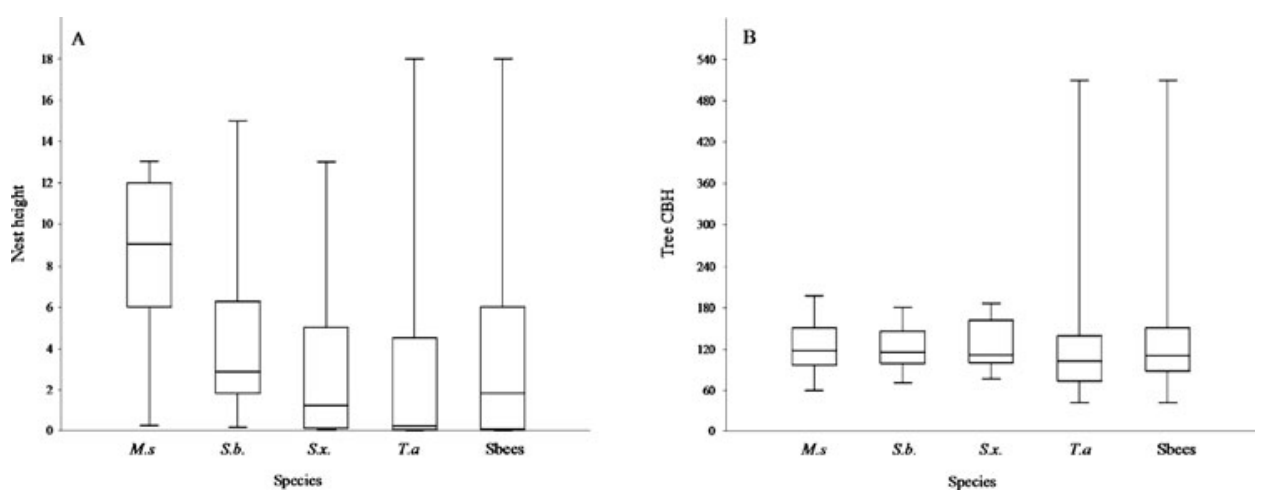

Figure 4 Box plots showing the frequency distributions of stingless bee nests in tree trunks in the Brazilian Atlantic rainforest at MER. a Tree cavity height. b Tree CBH. M.s $=$ M. scutellaris; S.b $=$ S. bipunctata; $S . x=S$. xanthotricha; $T . a=T$. angustula; Sbees $=$ total stingless bees

MER suggest that the availability of tree nesting sites in the forest is not limiting stingless bees.

Indirect evidence that tree nesting sites are underused by local communities of stingless bees is the unexpected abundance of the invading matrix species T. angustula in both forest categories. With high swarming rates, this species mainly occupy open areas or the edges of secondary forests (Batista et al. 2003; Slaa 2006, Silva et al. unpublished). Its swarming rate is significantly higher during the early stages of forest regeneration than in old growth forest sites of the Brazilian Atlantic rainforest (Batista et al. 2003, Silva et al. unpublished), and projected longevity of its colonies in the tropical lowlands of Costa Rica was significantly higher in open areas than in forests (Slaa 2006). Therefore, the abundance of T. angustula in the old growth forest is probably maintained by a "mass effect" (sensu Cody 1989) due to high input rates of propagules (swarms) from surrounding anthropogenic habitats, where this species can also reach very high nest densities (Silva et al. unpublished). This high propagule pressure is likely disrupting the internal controlling mechanisms in the forest community of stingless bees (see below).

Colony densities may be influenced by the high energy consumption of stingless bee communities as a whole (Roubik 1993), and by the economic constraints of their central place foraging (e.g., Kleinert et al. 2012), the efficiency of which should depend on patchy floral resources in tropical rainforest canopies (Ramalho 2004). Eltz et al. (2002), for example, concluded that irregular (supra-annual) mass flowering in the dipterocarp forests of southeastern Asia may be one of the main factors determining the reduced nest densities and low diversities of Meliponini found there - in comparison to adjacent disturbed vegetation areas with more regular annual flowering patterns.

None of the abundant species of stingless bees in the MER showed any clear preference for nesting in any particular sized tree or tree species (Silva et al. unpublished). Based on the raw data of nesting sites in the forests of Guyana and Panama (Roubik 1979, 1983), it could also be concluded that large and small bodied species of stingless bees did not exhibit marked preferences for specific tree diameters and heights, although Roubik (1983) noted that the size of the opening into a tree cavity could influence site suitability for some species and that only Melipona species and Trigona capitata zexmeniae [= Cephalotrigona zexmeniae (Cockerell 1912)] regularly used cavities with large openings in a forest community harboring 27 stingless bee species. In the MER, the lack of significant influence of large sized trees $(\mathrm{CBH}>110 \mathrm{~cm})$ on the spatial structuring of stingless bee communities was unexpected. It was expected, for example, that the large colonies of M. scutellaris, with high fidelity to the forest, were more common in the old growth forest, 
where large tree trunks were also more abundant at higher heights.

Particularly, the high similarity in the distribution of nests of Scaptotrigona species (including the heights and sizes of used cavities in trees) puts in check the argument of limiting similarity (Biesmeijer and Slaa 2006) based on the fact that "assemblages tend to consist largely of bees of different genera." This situation is relevant because Scaptotrigona species have fairly similar diets and they present foraging specialization using only a few productive sources - a pattern independently demonstrated through pollen analysis (e.g., Ramalho 1990; Kleinert et al. 2012) and records of floral visits (e.g., Biesmeijer and Slaa 2006).

In summary, contrary to expectations, the community structures of stingless bees did not appear to respond to the dynamics of the forests in the MER - indicating that spatial changes in the vegetation structure and, in particular, the density of large trees in old growth forests were not influencing the availability or the use of nesting sites - so that the same few and abundant species appear to be shaping the dynamics of nesting site use in the community independent of stages of forest regeneration.

In the forest habitat, if stingless bees invest more resources in colony survival rather than in reproduction (Slaa 2006), an expected result would be spatial and temporal stability. In other words, high colony longevity (Slaa 2006) associated with low swarming rates (Silva et al. unpublished) should buffer nest density fluctuations along the forest regeneration. Once a threshold of minimum tree cavity size availability is reached as forest regeneration proceeds (e.g., $\mathrm{CBH}>50 \mathrm{~cm}$ ), the community of stingless bees would tend to enter a lower turnover state, in which behavioral mechanisms (e.g., Hubbell and Johnson 1977; Johnson and Hubbell 1984) would become more prominent in regulating nest density.

Alternatively, the stochasticity that permeates the dynamics of the occupation of clearings in tropical rainforests, with neutralizing effects on latent competition in highly diverse tree communities (Hubbell et al. 2001), should also act on social bees that critically depend on the mass canopy flowering (Ramalho 2004) and tree trunks as nesting sites.

\section{ACKNOWLEDGMENTS}

We are grateful to Michelin for logistic support, CAPES for providing the doctoral grant to the first author, as well as CNPq (process numbers 481113/ 2004-5 and 478271/2008) and FAPESB (APR0114/ 2006) for financial support. We also thank the ECOPOL team at UFBA for their help with the fieldwork.

Diversité et utilisation de l'habitat par les abeilles sans aiguillon (Apidae) dans la forêt Atlantique brésilienne

\section{Meliponini / site de nidification / arbre / densité}

Diversität und Habitatnutzung bei stachellosen Bienen (Apidae) des brasilianischen atlantischen Waldes

\section{Meliponini / Nistplätze / Baumsubstrate}

\section{REFERENCES}

Adams, J. (2009) Species Richness: Patterns in the Diversity of Life. Praxis, Chichester. 396 p

Anderson, M.J. (2005) Permanova: Permutational Multivariate Analysis of Variance-A Computer Program. Department of Statistics, University of Auckland, New Zealand

Batista, M.A., Ramalho, M., Soares, A.E.E. (2003) Nesting sites and abundance of Meliponini (Hymenoptera: Apidae) in heterogeneous habitats of the Atlantic rain forest, Bahia. Brazil. Lund. 4, 19-23

Biesmeijer, J.C., Slaa, J. (2006) The structure of eusocial bee assemblages in Brazil. Apidologie 37, 240-258

Bray, J.R., Curtis, J.T. (1957) An ordination of the upland forest communities of southern Wisconsin. Ecol. Monogr. 27, 325-49

Brown, J.C., Albrecht, C. (2001) The effect of tropical deforestation on stingless bees of the genus Melipona (Insecta: Hymenoptera: Apidae: Meliponini) in central Rondonia. Brazil. J. Biogeogr. 28, 623-634

CEI-Conder-Ba (1993) Informações básicas dos municípios baianos: Litoral Sul. Salvador, 1993. v 5. 1100 p.

Chao, A. (2005) Species richness estimation. In: Balakrishnan, N., Read, C.B., Vidakovic, B. (eds.) Encyclopedia of Statistical Sciences, pp. 7909-7916. Wiley, New York

Clark, P.J., Evans, F.C. (1954) Distance to nearest neighbour as a measure of spatial relationships in populations. Ecol. 35, 445-453 
Cody, M.L. (1989) Discussion: structure and assembly of communities. In: Roughgarden, J., May, R.M., Levin, S.A. (eds.) Perspectives in Ecological Theory, pp. 203226. Princeton University Press, New Jersey

Eltz, T., Brühl, C.A., Kaars, S.V., Linsenmair, K.E. (2002) Determinants of stingless bee nest density in lowland dipterocarp forests of Sabah. Malaysia. Oecol. 131, 27-34

Eltz, T., Brühl, C.A., Kaars Imiyabir, Z., Linsenmair, K.E. (2003) Nesting and nest trees of stingless bees (Apidae: Meliponini) in lowland dipterocarp forests in Sabah, Malaysia, with implications for forest management. For. Ecol. Manage. 172, 301-313

Flesher, K.M. (2006). The biogeography of the medium and large mammals in a umandominated landscape in the Atlantic Forest of Bahia, Brazil: evidence for the role of agroforestry systems as wildlife habitat. Doctoral Thesis. Program in Ecology and Evolution. School-New Brunswick Rutgers, The State University of New Jersey. $624 \mathrm{p}$

GraphPad Software (1998). [computer program] Version 3.05 San Diego (CA): GraphPad Software, Inc

Hubbell, S.P. (2001) The unified neutral theory of biodiversity and biogeography. Princeton University Press, Princeton

Hubbell, S.P., Johnson, L.K. (1977) Competition and nest spacing in a tropical stingless bee community. Ecol. 58, 950-963

Johnson, L.K., Hubbell, S.P. (1974) Aggression and competition among stingless bees: field studies. Ecol. 55, 120-127

Johnson, L.K., Hubbell, S.P. (1975) Contrasting foraging strategies and coexistence of two bee species on a single resource. Ecol. 56, 1398-1406

Johnson, L.K., Hubbell, S.P. (1984). Nest tree selectivity and density of stingless bee colonies in a Panamanian forest. In: Chadwick, A.C. and Sutton L. (eds). Tropical rain forest: the Leeds Philosophical Symposium, pp. 147-154.

Johnson, L.K., Hubbell, S.P., Feener, D.H. (1987) Defense of food supply by eusocial colonies. Americ. Zool. 27, 347-358

Kenney, A.J., Krebs, C.J. (2000) Programs for Ecological Methodology, 2nd edn. Department of Zoology University of British Columbia, Vancouver

Kleinert, A.M.P. (2006). Demografia de ninhos de meliponíneos em biomas neotropicais. Tese (Livre Docência). Universidade de São Paulo. São Paulo, SP. 93p

Kleinert, A.M.P., Ramalho, M., Laurino, M.C., Ribeiro, M.F., Impetratriz-Fonseca, V.L. (2012) Social bees (Meliponini, Apinini, Bombini). In: Panizzi, A.R., Parra, J.R.P. (eds.) Insect Bioecology and Nutrition for Integrated Pest Management, pp. 237-271. CRC, Boca Raton

Köppen, W. (1948) Climatologia: con un estudio de los climas de la terra, p. 479p. Fondo Cult. Econ, México

McCune, B., Grace, J.B. (2002) Distance measures. In: Mc-Cune, B., Grace, J.B. (eds.) Analysis of Ecological
Communities. MjM Software Design, Gleneden Beach. Chapter 6

Michener, C.D. (2000) The Bees of the World. Johns Hopkins University, Baltimore. 913p

Nogueira-Neto, P. (1970) A criação de abelhas indígenas sem ferrão. Editora Chácaras e Quintais, São Paulo. $365 \mathrm{p}$

Nogueira-Neto, P. (1997) Vida e criação de abelhas indígenas sem ferrão, p. 445p. Nogueirapis, São Paulo

Oliveira, M.L., Morato, E.F., Garcia, M.V.B. (1995) Diversidade de espécies e densidade de ninhos de abelhas sociais sem ferrão (Hymenoptera, Apidae, Meliponinie) em floresta de terra firme na Amazônia Central. Rev. Bras. Zool. 12(1), 13-24

R Development Core Team (2011). R: a language and environment for statistical computing. R Foundation for Statistical Computing, Vienna, Austria. ISBN 3900051-07-0, URL http://www.R-project.org/.

Ramalho, M. (1990) Foraging by stingless bees of the genus Scaptotrigona (Apidae, Meliponinae). J. Apic. Res. 29, 61-67

Ramalho, M. (2004) Stingless bees and mass flowering trees in the canopy of Atlantic Forest: a tight relationship. Acta. Bot. Bras. 18(1), 37-47

Ramalho, M., Silva, M.D., Carvalho, C.A.L. (2007) Dinâmica de uso de fontes de pólen por Melipona scutellaris Latreille (Hymenoptera, Apidae): Uma Análise Comparativa com Apis mellifera L. (Hymenoptera, Apidae), no Domínio Tropical Atlântico. Neotropical Entomology 36, 38-45

Roubik, D.W. (1979) Nest and colony characteristics of stingless bees from French Guianas (Hymenoptera: Apidae). J. Kansas Entomol. Soc. 52, 443-470

Roubik, D.W. (1983) Nest and colony characteristics of stingless bees from Panama (Hymenoptera: Apidae). J. Kansas Entomol. Soc. 56, 327-355

Roubik, D.M. (1989) Ecology and Natural History of Tropical Bees. Cambridge University Press, London. 514p

Roubik, D.W. (1993) Direct costs of forest reproduction, bee-cycling and the efficiency of pollination modes. Journal of Biosciences 18, 537-552

Roubik, D.M. (2006) Stingless bees nesting biology. Apidologie 37, 124-143

Roughgarden, J. (1989) The structure and assembly of communities. In: Roughgarden, J., May, R.M., Levin, S.A. (eds.) Perspectives in Ecological Theory, pp. 203226. Princeton University Press, Princeton

Slaa, E.J. (2006) Population dynamics of a stingless bee community in the seasonal dry lowlands of Costa Rica. Ins. Soc. 53, 70-79

Sutherland, W.J. (1996) Ecological Census Techniques. Cambridge University Press, Cambridge

Vergara, C.B., Villa, A.L., Nates-Parra, G. (1986) Nidificación de meliponinos (Hymenoptera: Apidae) de la región central de Colombia. Rev. Bio. Trop. 34, 181-184 